\title{
PENDUDUK POLITIK PADA PEMILIHAN GUBERNUR PROPINSI DAERAH KHUSUS IBU KOTA JAKARTA 2017: Dinamika Data Pemilih Putaran Pertama dan Putaran Kedua
}

\author{
Oleh: Rahmatulloh*
}

\begin{abstract}
This Study is to describe the updating of voters data used in the 2017 Gubernatorial and Vice Governor Election both in the first and second rounds. Description begins from the residence data of the Ministry of Home Affairs in the form of DP4 submitted to the KPU to be updated and the final result becomes DPT. The problem of voters data arises regarding the certainty of population data that has not fully reached the development of the population due to the limitations so that the voters use the proof of residence in the form of Electronic ID and Suket in DPTb for voting in TPS. The result of data voters local election in DKI 2017 accuracy level still not according to public expectation.
\end{abstract}

Keywords: Population, Politics, Voters, Local Election, Jakarta.

\section{PENDAHULUAN}

\section{A. Latar Belakang}

DKI Jakarta baru saja menjalani perhelatan demokrasi lokal yakni pemilihan pasangan Gubernur dan Wakil Gubernur yang umumnya dikenal Pilkada, atau kerap disebut Pilgub sebagai daerah provinsi dengan otonomi khusus. Sebagaimana Pasal 18 ayat (4) UUD 1945 dinyatakan bahwa Kepala Daerah otonom, yakni Gubernur, Bupati, dan Walikota dipilih secara demokratis. Bagi DKI Jakarta selain berlaku UU No. 1 Tahun 2015 mengenai Pemilihan Gubernur, Bupati dan Walikota yang telah diubah UU No. 8
Tahun 2015 dan UU No. 10 Tahun 2016, juga berlaku UU No. 29 tahun 2007 tentang Pemerintahan Provinsi Daerah Khusus Ibukota Jakarta Sebagai Ibukota Negara Kesatuan Republik Indonesia yang di dalamnya terdapat aturan mengenai ketentuan jumlah pemenangan suara sebagai Gubernur terpilih.

Pada pemungutan Suara Pilgub DKI Jakarta Tahun 2017 Putaran Pertama telah diketahui secara resmi akhirnya oleh KPU Provinsi DKI Jakarta pada 26 Maret 2017 bahwa perolehan (1) Pasangan Calon Gubernur dan Wakil Gubernur Nomor Urut 1 
Agus Harimurti Yudhoyono M. Sc. , MPA. , MA. dan Prof. Dr. Hj. Sylviana Murni, SH. M. Si. mendapat 937. 955 suara atau 17,05 persen, (2) Pasangan Calon Gubernur dan Wakil Gubernur Nomor Urut 2 Ir. Basuki Tjahaja Purnama MM. dan Drs. H. Djarot Saiful Hidayat M. Si. mendapat 2. 364. 577 suara atau 42,99 persen, dan (3) Pasangan Calon Gubernur dan Wakil Gubernur Nomor Urut 3 Anies Rasyid Baswedan, Ph. D. dan Sandiaga Salahuddin Uno, MBA. mendapat 2. 197. 333 atau 39. 95 persen suara dari jumlah total suara sah sebanyak 5. 499. . 865 dan suara tidak sah mencapai 64. 448 dari sebanyak 5. 564. 313 pemilih yang mengikuti pemungutan suara pada 15 Februari 2017.

Dilihat dari segi jumlah pemilih yang tercantum dalam DPT sebesar 7. 108. 589 berarti terjadi pengurangan pemilih yang menggunakan hak suaranya, meskipun jumlah pemilih di luar DPT sudah terjadi penambahan pada saat hari pemungutan suara, yakni Daftar Pemilih Tambahan (DPTb) sebanyak 237. 003 yang digunakan pada saat pencoblosan berakhir. Dari jumlah pemilih yang menggunakan hak pilihnya sebanyak 5. 564. 313, maka tingkat partisipasi pemilih sebesar 75,75 persen. Pada Pilkada DKI Jakarta 2017 Putaran Pertama ini setidaknya tergambarkan bahwa terjadi peningkatan partisipasi pemilihnya dibandingkan pada Pilkada DKI Jakarta 2012 yang diikuti sebanyak 68 persen.

Dalam catatan Badan Kesatuan Bangsa dan Politik Pemerintah Provinsi DKI Jakarta dinyatakan bahwa peningkatan partisipasi pemilih pada Pilkada 2017 putaran pertama ini diantaranya faktor keikutsertaan pemilih yang tinggal di permukiman mewah Ibukota yang selama ini enggan ikut memilih, selain masih banyaknya warga yang memilih menggunakan identitas kependudukannya pada satu jam terakhir (Rakyat Merdeka Online (RMOL) Jumat, 17 februari 2017, http://m. rmoljakarta. com/news. php?id=42689).

Berdasarkan rekapitulasi suara dari masing-masing perolehan pasangan calon gubernur dan wakil gubernur sebagaimana di atas, tidak ada yang meraih suara $50 \%$ lebih untuk menjadi pemenang sesuai ketentuan yang diatur dalam UU Nomor 29 Tahun 2007 tentang Pemerintahan Provinsi Daerah Khusus Ibukota Jakarta Sebagai Ibukota Negara Kesatuan Republik Indonesia

Dengan demikian, KPU Provinsi DKI Jakarta kemudian menetapkan Pasangan Calon Gubernur dan Wakil Gubernur Nomor Urut 2 Ir. Basuki Tjahaja Purnama MM. dan Drs. H. Djarot Saiful Hidayat M. Si. dan Pasangan Calon Gubernur dan Wakil 
Gubernur Nomor Urut 3 Anies Rasyid Baswedan, Ph. D. dan Sandiaga Salahuddin Uno, MBA. untuk menjadi peserta "kompetitor" Pasangan Calon Peserta Pemilihan Gubernur dan Wakil Gubernur Provinsi DKI Jakarta Tahun 2017 Putaran Kedua. Pada pemungutan suara Pilgub DKI 2017 Putaran Kedua 19 April 2017 hasil akhirnya secara resmi pada Rapat Pleno Terbuka Rekapitulasi Hasil Penghitungan Suara Tingkat Provinsi oleh KPU Provinsi DKI Jakarta, 29 April 2017 didapati perolehan suara berikut:

1. Pasangan Calon Gubernur dan Wakil Gubernur Nomor Urut 2 Ir. Basuki Tjahaja Purnama MM. dan Drs. H. Djarot Saiful Hidayat M. Si. meraih 2. 350.366 suara atau 42,04 persen

2. Pasangan Calon Gubernur dan Wakil Gubernur Nomor Urut 3 Anies Rasyid Baswedan, Ph. D. dan Sandiaga Salahuddin Uno, MBA. meraih 3. 240. 987 atau 57. 96 persen.

Dari semua pasangan calon tersebut, jumlah perolehan suara sah totalnya mencapai sebanyak 5.591. 353 serta terdapat jumlah suara tidak sah mencapai 58. 075 dan secara keseluruhan Pilgub diikuti oleh sebanyak 5. 649. 428 pemilih. Jumlah pemilih yang tercantum dalam DPT sebesar 7. 218. 280 dan Daftar Pemilih Tambahan (DPTb) Putaran Kedua sebanyak 111. 286 yang digunakan pada saat pencoblosan. Dari jumlah tersebut jumlah pemilih yang menggunakan hak pilih hanya diikuti sebanyak 5. 649. 428 sehingga tingkat partisipasi pemilih Putaran Kedua Pilgub DKI 2017 sebesar 77,08 persen.

Meskipun Pilkada DKI Jakarta 2017 telah dilalui dengan baik dan berjalan lancar tanpa gangguan berarti, namun dibalik kesuksesan tersebut masih terdapat kekisruhan di berbagai tempat di beberapa wilayah DKI Jakarta khususnya terkait dengan data pemilih.

Problem mengenai data pemilih pada Pilgub DKI Jakarta 2017 diduga terjadi sejak pemutakhiran data pemilih sementara hingga menjadi Daftar Pemilih Tetap (DPT) yang belum mengakomodir kepentingan warga Ibukota secara keseluruhan, termasuk temuan identitas penduduk ganda atau lebih hingga keraguan pada identitas warga pemilih yang terdaftar. Akibatnya kericuhan yang ditimbulkan yakni membludaknya pemilih yang mendaftar sebagai pemilih tambahan, sebagaimana pada pemungutan suara Putaran Pertama yakni pemilih yang menggunakan identitas kependudukan seperti E-KTP maupun Surat Keterangan karena tidak 
terdaftar dalam DPT untuk mencoblos pada 15 Februari.

Para warga yang berbondongbondong ke TPS tersebut berupaya untuk dapat dicatat dalam "daftar pemilih tambahan" agar dapat menggunakan hak pilihnya, namun karena keterbatasan waktu dan kertas suara, dan maupun persoalan teknis dan kecakapan (profesionalisme) penyelenggara di tingkat PPS dan KPPS, masih terdapat banyak warga yang tidak dapat menggunakan hak politiknya. Akibatnya muncul sejumlah protes warga yang tidak dapat memilih, dan bahkan warga mempertanyakan netralitas dan integritas petugas KPPS akibat pembiaran membludaknya "Pemilih Tambahan". Tidak ayal lagi, pasca pemungutan suara, usai dilakukan penghitungan ternyata jumlah pemilih tambahan yang terdaftar dalam Daftar Pemilih Tambahan (DPTb) yang cukup banyak dan menimbulkan kecurigaan warga sebagai bentuk pengerahan massa pemilih yang sengaja "digerakkan" di beberapa TPS.

Perjalanan data Daftar Pemilih pada setiap hajatan Pilgub DKI yang pernah ada (2007, 2012, hingga kini 2017) selalu problematis. Dengan demikian perlu diungkap kembali sejauhmana dinamika data pemilih pada Pilgub DKI Jakarta 2017, baik pada Putaran Pertama maupun pada Putaran Kedua.

\section{B. Dasar Hukum dan Acuan Konseptual}

\section{Hakikat Pemilih}

Warga negara yang menjadi pemilih dalam Pilgub sesuai pasal 56 pada UndangUndang Republik Indonesia Nomor 1 Tahun 2015 Tentang Penetapan Peraturan Pemerintah Pengganti Undang-Undang Nomor 1 Tahun 2014 Tentang Pemilihan Gubernur, Bupati, dan Walikota Menjadi Undang-Undang adalah: (1) Warga negara Indonesia yang pada hari pemungutan suara sudah berumur 17 (tujuh belas) tahun atau sudah/pernah kawin, mempunyai hak memilih; (2) Didaftar 1 (satu) kali oleh penyelenggara Pemilu; (3) Jika Pemilih mempunyai lebih dari 1 (satu) tempat tinggal, Pemilih tersebut harus memilih salah satu tempat tinggalnya yang dicantumkan dalam daftar pemilih berdasarkan Kartu Tanda Penduduk Elektronik dan/atau surat keterangan domisili dari Kepala Desa atau sebutan lain/ Lurah.

Selanjutnya ketentuan pemilih mengalami perubahan sebagaimana dalam Pasal 57 Undang-Undang Republik Indonesia Nomor 10 Tahun 2016 Tentang Perubahan Kedua Atas Undang-Undang 
Nomor 1 Tahun 2015 Tentang Penetapan Peraturan Pemerintah Pengganti UndangUndang Nomor 1 Tahun 2014 Tentang Pemilihan Gubernur, Bupati, dan Walikota Menjadi Undang-Undang disebutkan yakni; (1) Untuk menggunakan hak memilih, warga negara indonesia harus terdaftar sebagai pemilih; (2) Dalam hal warga negara Indonesia tidak terdaftar sebagai pemilih sebagaimana dimaksud pada ayat (1), pada saat pemungutan suara menunjukkan kartu tanda penduduk Elektronik; (3) Untuk dapat didaftar sebagai pemilih, warga negara Indonesia sebagaimana dimaksud pada ayat (1) harus memenuhi syarat; (a) Tidak sedang terganggu jiwa/ingatannya; dan/atau (b) Tidak sedang dicabut hak pilihnya berdasarkan putusan pengadilan yang telah mempunyai kekuatan hukum tetap; (4) Warga negara Indonesia yang tidak terdaftar dalam daftar pemilih dan saat pemungutan suara tidak memenuhi syarat sebagaimana dimaksud pada ayat (2) ayat ayat (3), yang bersangkutan tidak dapat menggunakan hak memilihnya.

\section{Hakikat Data Pemilih}

Data pemilih ialah sekumpulan daftar penduduk berstatus dewasa sebagai pemilih. Seringkali Data pemilih diartikan berisikan sekumpulan warga penduduk yang memiliki hak pilih yang didaftar untuk menggunakan hak pilihnya dalam pemilihan umum.

Lengkapnya data pemilih adalah data yang berisikan daftar penduduk yang menjadi pemilih setelah diproses melalui konsolidasi, verifikasi dan validasi sebagai Data Penduduk Potensial Pemilih atau disingkat DP4 oleh Pemerintah selanjutnya disinkronisasikan dengan daftar pemilih pada Pemilu terakhir dan dimutakhirkan oleh penyelenggara Pemilu untuk kepentingan pelaksanaan pemilihan umum.

\section{Hakikat Data Penduduk Potensial Pemilih (DP4)}

DP4 berisikan daftar penduduk yang memenuhi syarat sebagai pemilih saat pemilihan diselenggarakan. DP4 berasal dari data kependudukan pada Dinas Kependudukan dan Pencatatan Sipil di daerah yang kemudian divalidasi oleh Pemerintah melalui Kementerian Dalam Negeri. DP4 disusun untuk kepentingan Pemilu yang akan dimutakhirkan oleh penyelenggara Pemilu.

DP4 memuat berbagai keterangan kependudukan warga negara meliputi: (a) Nomor urut, (b) Nomor Induk Kependudukan, (c) Nomor Kartu Keluarga, (d) Nama Lengkap, (e) Tempat Lahir, (f) Tanggal Lahir, (g) Umur, (h) Jenis kelamin, 
(i) Status Perkawinan, (j) Alamat Jalan, (k) Rukun Tetangga/RT, (l) Rukun Warga/RW, dan (m) Jenis Disabilitas.

DP4 disampaikan oleh pemerintah kepada penyelenggara Pemilu (KPU) sebelum dilakukannya tahapan pemutakhiran data pemilih.

\section{Hakikat Data Hasil Sinkronisasi DP4 dengan Daftar Pemilih Pada Pemilu Terakhir}

Data Hasil Sinkronisasi DP4 dengan Daftar Pemilih pada Pemilu terakhir adalah kegiatan yang dilakukan oleh KPU selaku penyelenggara Pemilu untuk mensinkronkan DP4 dengan Daftar Pemilih yang terakhir kali dilakukan sebelum diadakan Pemilihan berikutnya. Dalam konteks ini pemilu terakhir adalah Daftar Pemilih yang pernah digunakan pada pemungutan suara Pemilihan Presiden 2014.

KPU menganalisis DP4 yang diterima dari Pemerintah berikutnya disinkronisasikan antara DP4 hasil analisis dengan data Pemilih pada Pemilu atau Pemilihan Terakhir dan selanjutnya dari hasil sinkronisasi kemudian diserahkan kepada KPU Provinsi dan KPU Kabupaten/Kota sebagai bahan pemutakhiran data. DP4 sebagai data sekunder oleh KPU hanya dijadikan pertimbangan untuk memproses pembaruan Daftar Pemilu terakhir sebagai data primer yang pernah digunakan.

\section{Hakikat Pemutahiran Data Pemilih,} Daftar Pemilih Sementara (DPS) dan Daftar Pemilih Sementara Hasil Perbaikan (DPS HP)

Pemutakhiran data adalah tahapan kegiatan memperbaharui data pemilih melalui pencatatan, perbaikan, pencoretan, dan maupun penambahan daftar pemilih yang memenuhi persyaratan menurut ketentuan yang diatur dalam peraturan perundangundangan sesuai dinamika kependudukan yang terjadi di wilayah/daerah pemilihan.

Pelaksanaan pemutakhiran data dengan cara menggunakan data hasil sinkronisasi DP4 dengan Pemilu terakhir untuk dilakukan pencocokan dan penelitian (Coklit) di lapangan oleh KPU melalui PPS dan Petugas pemutakhiran yang dibentuk. Dengan demikian, untuk keperluan perbaharuan data dengan cara melakukan verifikasi faktual data Pemilih di lapangan maka dibentuk Petugas Pemutakhiran Data Pemilih (PPDP) yang dibentuk KPU Kabupaten/Kota. Adapun DPS yang telah diperbaiki berdasarkan saran, masukan, dan koreksi dari masyarakat luas untuk penyempurnaan daftar pemilih selama sosialisasi dilakukan melalui pemutakhiran 
ulang disebut DPS Hasil Perbaikan atau dikenal DPS HP. DPS HP inilah yang kemudian kelak disahkan menjadi DPT melalui proses rapat pleno terbuka yang diselenggarakan oleh KPU.

\section{Hakikat Daftar Pemilih Tetap (DPT), Daftar Pemilih Pindahan (DPPh), dan Daftar Pemilih Tambahan (DPTb)}

DPT adalah data pemilih yang ditetapkan oleh KPU yang berisi daftar penduduk pemilih untuk menggunakan hak memilih dan diumumkan oleh KPU melalui PPS pada Pemilihan yang telah ditentukan.

Daftar identitas pemilih tetap pemilu dalam DPT terdiri susunan nama penduduk WNI yang telah memenuhi syarat sebagai Pemilih berdasarkan undang-undang dan berhak menggunakan haknya untuk memberikan suara di TPS dalam Pemilu. Penduduk yang telah terdaftar dalam DPT diberi surat pemberitahuan sebagai pemilih oleh PPS.

Selain DPT, juga terdapat Daftar Pemilih Pindahan (DPPh), yakni daftar yang berisi Pemilih yang telah terdaftar dalam DPT yang menggunakan hak pilihnya di TPS lain yang biasanya karena statusnya yang pindah alamat atau karena pekerjaan saat menjelang pemilihan. Contohnya adalah petugas kesehatan di Rumah Sakit, petugas Lembaga Pemasyarakatan (LAPAS), petugas keamanan atau Satpam di perkantoran atau perumahan, petugas Dinas Kebersihan yang bekerja di lapangan yang jauh dari alamat tinggalnya atau mereka yang pindah alamat tempat tinggal karena sesuatu hal seperti penggusuran maupun kontrak atau kedinasan.

Daftar Pemilih Tambahan (DPTb) adalah adalah daftar Pemilih yang tidak terdaftar sebagai Pemilih dalam DPT, namun memenuhi syarat dilayani penggunaan hak pilihnya pada hari dan tanggal pemungutan suara, memiliki KTP Elektronik atau Surat Keterangan (Suket) dari Disdukcapil.

\section{Hakikat Surat Keterangan (SUKET)}

\section{Disdukcapil Khusus Pemilu}

Surat Keterangan

(SUKET)

Disdukcapil khusus Pemilu sebagaimana disebutkan di atas adalah diberikan bagi penduduk WNI yang belum terdaftar sebagai pemilih dalam DPT namun memenuhi syarat tetap dapat menggunakan hak pilihnya pada hari dan tanggal pemungutan suara dengan menggunakan Surat Keterangan dari Disdukcapil karena sudah terekam dalam sistem Elektronik KTP namun belum mendapatkan bukti fisik Kartu Tanda Penduduk Elektronik (E-KTP). Jadi SUKET adalah pengganti E-KTP sementara 
yang digunakan untuk kepentingan Pemilihan.

Mengacu pada pasal 61 UU No. 10/2016, yang berbunyi sebagai berikut:

1. Dalam hal masih terdapat penduduk yang mempunyai hak pilih belum terdaftar dalam daftar Pemilih tetap, yang bersangkutan dapat menggunakan hak pilihnya dengan menunjukkan Kartu Tanda Penduduk Elektronik.

2. Penggunaan hak pilih sebagaimana dimaksud pada ayat (1) hanya dapat digunakan ditempat pemungutan suara yang berada di rukun tetangga atau rukun warga atau sebutan lain sesuai dengan alamat yang tertera dalam Kartu Tanda Penduduk Elektronik.

3. Sebelum menggunakan hak pilihnya penduduk sebagaimana dimaksud pada ayat (1) terlebih dahulu mendaftarkan diri pada KPPS setempat dan dicatat dalam daftar Pemilih tambahan.

4. Penggunaan hak pilih penduduk sebagaimana dimaksud pada ayat (1), dilakukan 1 (satu) jam sebelum selesainya pemungutan suara di TPS. Bagi penduduk yang hendak menggunakan hak pilihnya dengan membawa KTP Elektronik atau SUKET karena tidak terdata dalam DPT, mendaftarkan diri pada KPPS setempat untuk dicatat dalam Daftar Pemilih Tambahan (DPTb) sebagaimana dijelaskan di atas.

\section{Hakikat DPS, DPTb, dan DPT Pilgub DKI} Jakarta Tahun 2017 Putaran Kedua

Pada Pilgub DKI 2017 Putaran Kedua, DPS diartikan sebagai hasil perbaikan terhadap Daftar Pemilih Tetap pada Putaran Pertama, Daftar Pemilih Tambahan di Putaran Pertama, pemilih berusia 17 (tujuh belas) tahun pada hari pemungutan suara pada Putaran Kedua, dan potensi pemilih yang belum terdaftar dalam DPT Putaran Pertama.

Daftar Pemilih Tambahan (DPTb) dalam Pilgub DKI Jakarta 2017 Putaran Kedua, ialah daftar Pemilih yang tidak terdaftar sebagai Pemilih dalam DPT Putaran Kedua namun memenuhi syarat sebagai pemilih untuk dilayani hak pilihnya pada hari dan tanggal pemungutan suara dengan menunjukkan KTP Elektronik atau Surat Keterangan yang dikeluarkan oleh Dinas Kependudukan dan Catatan Sipil Pemerintah Provinsi DKI Jakarta sesuai ketentuan dan dilengkapi dengan menunjukkan Kartu Keluarga (asli) pada Putaran Kedua. 


\section{PEMBAHASAN}

\section{A. Data Pemilih Pilgub DKI 2017 Putaran Pertama}

\section{Hasil DP4 di Kementerian Dalam Negeri dan Sinkronisasi DP4 dengan Data Pilpres 2014 di KPU}

$$
\text { Disdukcapil DKI telah }
$$

mengirimkan Data Kependudukan Provinsi DKI hasil pelaporan Semester II Desember 2015 ke pihak Kementerian Dalam Negeri untuk disinkronisasi, diverifikasi dan divalidasi menjadi DP4. Kemudian setelah
DP4 disusun oleh Pemerintah melalui Kemendagri diserahkan ke KPU Pusat pada 14 Juli 2016.

KPU kemudian menganalisis DP4 dan melakukan sinkronisasi DP4 Hasil Analisis dengan Data Pemilih pada Pemilu atau pemilihan terakhir sebagaimana sesuai Pasal 7 Peraturan Komisi Pemilihan Umum (PKPU) Nomor 4 Tahun 2015. Jumlah potensial pemilih dalam DP4 sebanyak $7,439,149$ sebagaimana pada tabel 1 berikut di bawah ini.

Tabel 1

Data DP4 Kemendagri Dianalisis KPU Pusat

\begin{tabular}{|c|c|c|c|}
\hline \multirow{2}{*}{ 6 Kabupaten/Kota } & \multicolumn{3}{|c|}{ Jumlah Pemilih Dalam DP4 } \\
\cline { 2 - 4 } & $\mathbf{L}$ & $\mathbf{P}$ & $\mathbf{L}+\mathbf{P}+\mathbf{N}$ \\
\hline TOTAL & $\mathbf{3 , 7 2 1 , 3 2 5}$ & $\mathbf{3 , 7 1 7 , 8 2 4}$ & $\mathbf{7 , 4 3 9 , 1 4 9}$ \\
\hline
\end{tabular}

Sesuai dengan aturan Pasal 58 UU Nomor 10 Tahun 2016 tentang Perubahan Kedua atas UU Nomor 1 tahun 2015 tentang Penetapan Perppu Nomor 1 Tahun 2014 tentang Pemilihan Gubernur, Bupati, dan Walikota menjadi Undang-Undang, maka
DPT pemilu terakhir merupakan sumber data utama dalam pemutakhiran data pemilih dan disinkronisasikan dengan DP4 sebagai data referensi atau data sekunder. Diketahui jumlah pemilih dalam DPT Pemilu terakhir (Pilpres 2014) pada tabel 2 berikut:

Tabel 2

Jumlah Pemilih DKI Jakarta Pada Pemilu Presiden dan Wakil Presiden Tahun 2014 


\begin{tabular}{|c|c|c|c|}
\hline Pemilu & $\begin{array}{c}\text { Jumlah dalam } \\
\text { DPT }\end{array}$ & $\begin{array}{c}\text { Menggunakan } \\
\text { Hak Pilih }\end{array}$ & $\begin{array}{c}\text { Tidak } \\
\text { Menggunakan } \\
\text { Hak Pilih }\end{array}$ \\
\hline $\begin{array}{l}\text { Pemilu Presiden dan } \\
\text { Wakil Presiden } \\
\text { Tahun } 2014\end{array}$ & 7.096 .168 & $\begin{array}{c}5.441 .705 \\
(76,7 \%)\end{array}$ & $\begin{array}{c}1.654 .463 \\
(23,3 \%)\end{array}$ \\
\hline
\end{tabular}

Pada tabel 2 di atas diketahui bahwa jumlah DPT Pilpres 2014 yang sebanyak 7. 096. 168 pemilih, dan kemudian disinkronisasikan dengan data DP4 yang jumlah sebanyak 7. 439. 149 penduduk potensial pemilih. Sebagaimana dalam tabel 3 di bawah ini.

Tabel 3

Jumlah Pemilih Hasil Sinkronisasi DP4 dan DPT Pilpres 2014

\begin{tabular}{|c|c|c|c|}
\hline \multirow{2}{*}{ 6 Kabupaten/Kota } & \multicolumn{3}{|c|}{ Jumlah Sinkronisasi DP4 dan DPT Pilpres } \\
\cline { 2 - 4 } & $\mathrm{L}$ & $\mathrm{P}$ & $\mathrm{L}+\mathrm{P}+\mathrm{N}$ \\
\hline TOTAL & $\mathbf{4 , 1 6 0 , 2 2 1}$ & $\mathbf{4 , 0 8 3 , 4 3 0}$ & $\mathbf{8 , 2 4 3 , 6 5 1}$ \\
\hline
\end{tabular}

Dari tabel 3 di atas hasil sinkronisasi DPT dan DP4 oleh KPU didapat sebanyak 8,243,651 pemilih sehingga menimbulkan persepsi yang beragam dari kalangan warga DKI akan kekhawatiran terjadinya penggelembungan pemilih pada Pilgub di DKI.
Sedangkan gambaran mengenai jumlah penduduk pemilih pemula dari hasil sinkronisasi yaitu potensial pemilih memasuki usia 17 tahun pada saat pemungutan suara diperkirakan sebanyak 387. 071 orang sebagaimana pada tabel 4 berikut.

\section{Tabel 4}

Jumlah Pemilih Hasil Sinkronisasi DP4 dan DPT Pilpres 2014 Dilihat Dari Segi Usia Potensi Pemilih Pemula dan Usia Bawah-Atas

\begin{tabular}{|c|l|r|r|r|r|r|}
\hline \multirow{2}{*}{\begin{tabular}{l} 
N \\
\cline { 3 - 7 }
\end{tabular}} & Nama & \multicolumn{3}{|c|}{ Pemilih Pemula } & \multicolumn{2}{c|}{ Di bawah 17 di atas 90 } \\
\cline { 3 - 7 } & Kabupaten/Kota & L & \multicolumn{1}{c|}{$\mathrm{P}$} & L+P+N & $<17$ & \multicolumn{1}{c|}{$>90$} \\
\hline 1 & Jakarta Pusat & 22,205 & 20.511 & 42,716 & 34 & 1,030 \\
\hline 2 & Jakarta Utara & 32,286 & 30,480 & 62,766 & 35 & 649 \\
\hline 3 & Jakarta Barat & 44,008 & 41,610 & 85,618 & 28 & 1,013 \\
\hline 4 & Jakarta Selatan & 42,143 & 40,761 & 82,904 & 18 & 1,059 \\
\hline 5 & Jakarta Timur & 57,512 & 54,313 & 111,825 & 42 & 1,038 \\
\hline
\end{tabular}




\section{JURNAL ILMIAH MIMBAR DEMOKRASI}

\begin{tabular}{|l|c|r|r|r|r|r|}
\hline 6 & Kepulauan Seribu & 632 & 610 & 1,242 & 1 & 15 \\
\hline & Total & 198,786 & 188,285 & 387,071 & 158 & 4,804 \\
\hline
\end{tabular}

Dari sebanyak $8,243,651$ hasil sinkronisasi tersebut masih "data kotor" yang perlu dimutakhirkan melalui proses pemutakhiran data pemilih. Sebab dalam data tersebut masih dijumpai berbagai masalah yaitu sekitar 1. 400. 000-an yang tidak sinkron dan hanya sekitar 6. 000 . 000-an yang sinkron antara DP4 dengan DPT Pilpres serta dugaan adanya sejumlah KTP ganda sebanyak 85. 000-an orang di DKI Jakarta.

\section{Pemutakhiran Data Pemilih, DPS, dan DPS HP}

Hasil sinkronisasi DP4 dan DPT terakhir dari KPU Pusat tersebut di atas kemudian diserahkan ke KPU Provinsi DKI Jakarta pada 13 Agustus 2016 untuk dikaji sebagai bahan pemutakhiran data pemilih. Data hasil sinkronisasi tersebut perlu dimutakhirkan karena sudah dipastikan belum akurat, karena banyak faktor ditemui di lapangan, berikut: banyak warga DKI Jakarta yang tinggal tidak sesuai alamat yang tercantum pada KTP, Data registrasi kependudukan DKI yang selalu dinamis, termasuk tercantumnya warga yang tidak memenuhi syarat sebagai pemilih seperti status sebagai anggota TNI, Polri, hingga warga yang hilang ingatan atau maupun yang dicabut hak pilihnya oleh pengadilan, adanya warga DKI yang memiliki KTP ganda dan adanya NIK palsu dan NIK yang tidak sinkron dengan nama dan jenis kelamin.

\section{Tabel 5}

Jumlah Pemilih Hasil Rekapitulasi DPS KPU Provinsi DKI Jakarta

Putaran Pertama

\begin{tabular}{|c|c|c|c|c|}
\hline NO & KOTA/KABUPATEN & JUMLAH & \multicolumn{2}{|c|}{ DPS } \\
\cline { 3 - 5 } & & KECAMATAN & TPS & PEMILIH \\
\hline 1 & JAKARTA PUSAT & 8 & 1.237 & 757.898 \\
\hline 2 & JAKARTA UTARA & 6 & 2.142 & 1.099 .169 \\
\hline 3 & JAKARTA BARAT & 8 & 2.934 & 1.669 .351 \\
\hline 4 & JAKARTA SELATAN & 10 & 3.033 & 1.599 .920 \\
\hline 5 & JAKARTA TIMUR & 10 & 3.681 & 1.989 .106 \\
\hline 6 & KEPULAUAN & 2 & 40 & 17.412 \\
& SERIBU & & & \\
\hline & JUMLAH & $\mathbf{4 4}$ & $\mathbf{1 3 . 0 6 7}$ & $\mathbf{7 . 1 3 2 . 8 5 6}$ \\
\hline
\end{tabular}


Tabel 6 Jumlah Pemilih Hasil Rekapitulasi DPS Berdasarkan Jenis Kelamin

\begin{tabular}{|c|c|c|c|c|}
\hline \multirow{2}{*}{$\begin{array}{l}\text { Jumlah } \\
\text { Kabupaten/K } \\
\text { ota }\end{array}$} & \multirow{2}{*}{$\begin{array}{l}\text { Jumlah } \\
\text { TPS }\end{array}$} & \multicolumn{3}{|c|}{$\begin{array}{l}\text { Jumlah Pemilih } \\
\text { Perempuan }\end{array}$} \\
\hline & & $\mathrm{L}$ & $\mathrm{P}$ & $\mathrm{L}+\mathrm{P}+\mathrm{N}$ \\
\hline 6 & 13.067 & $\begin{array}{c}\text { 3. } 576 . \\
091\end{array}$ & 3. $\begin{array}{c}556 \\
765\end{array}$ & 7. 132.856 \\
\hline
\end{tabular}

Selain Rekapitulasi DPS di atas, KPU DKI Jakarta juga merekapitulasi jumlah pemilih potensial pemilih Non KTP Elektronik dan sebagainya yang masih bermasalah untuk mendapatkan klarifikasi, penjelasan dan perbaikan dari pihak terkait yakni pemerintah, yakni Disdukcapil, Lapas, dan sebagainya serta masyarakat sebagaimana tabel 7 berikut:

Tabel 7

Jumlah Pemilih Potensial Non KTP Elektronik Hasil Rekapitulasi KPU DKI

\begin{tabular}{|c|l|l|c|c|}
\hline \multirow{2}{*}{$\begin{array}{l}\text { Jumlah } \\
\text { Kabupaten/Kota }\end{array}$} & \multicolumn{1}{|c|}{$\begin{array}{l}\text { Jumlah Pemilih } \\
\text { Jumlah } \\
\text { TPS }\end{array}$} & $\mathrm{L}$ & $\mathrm{P}$ & $\mathrm{L}+\mathrm{P}+\mathrm{N}$ \\
\cline { 2 - 5 } & 12.847 & 271.262 & 233.348 & 504.610 \\
\hline 6 & \multicolumn{2}{|l}{} \\
\hline
\end{tabular}

Dengan demikian terdapat angka pemilih sebagai warga DKI yang telah merekam identitasnya pada E-KTP dan warga pemilih non E-KTP atau sebab lainnya yang tercantum dalam DPS. Dengan adanya angka penduduk belum merekam E-KTP dan masalah lainnya sejumlah 504. 610 warga sebagaimana di atas karena data pemilih masih berupa DPS yang mesti diperbaiki, namun masalah database kependudukan di pemerintahan sehingga menjadi dilema tersendiri karena menyangkut status kependudukan secara yuridis. Dalam hal ini KPU DKI harus berkordinasi dengan Disdukcapil DKI Jakarta dalam melakukan verifikasi dan validasi data kependudukan.

Hasil akurasi data DPS tersebut di lakukan kembali dalam Rapat Pleno Rekapitulasi Perbaikan DPS kemudian 
menjadi DPS Hasil Perbaikan (DPSHP). Dalam Rapat Koordinasi Pelaksanaan Pemutakhiran Data Pemilih pada 4 Desember 2016 diselenggarakan KPU Provinsi DKI menjelang penetapan DPT sesuai batas waktu tinggal 2 hari lagi (8 Desember 2016 di tingkat Provinsi) dipaparkan beberapa hasil perbaikan DPS yang telah mengalami perubahan di tingkat PPS hingga Kota/Kabupaten sebagaimana pada tabel 8 berikut:

Tabel 8

Jumlah Pemilih Berdasarkan DPS Hasil Perbaikan (DPSHP) Provinsi DKI Jakarta Putaran Pertama

\begin{tabular}{|c|c|c|c|c|}
\hline \multirow[t]{2}{*}{ NO } & \multirow[t]{2}{*}{ KOTA/ KABUPATEN } & \multirow{2}{*}{$\begin{array}{c}\text { JUMLAH } \\
\text { KECAMATA } \\
\mathbf{N}\end{array}$} & \multicolumn{2}{|c|}{ DPS HP } \\
\hline & & & TPS & PEMILIH \\
\hline 1 & JAKARTA PUSAT & 8 & 1.236 & 752.607 \\
\hline 2 & JAKARTA UTARA & 6 & 2.146 & 1.098 .932 \\
\hline 3 & JAKARTA BARAT & 8 & 2.934 & 1.662 .269 \\
\hline 4 & JAKARTA SELATAN & 10 & 2.973 & 1.607 .445 \\
\hline 5 & JAKARTA TIMUR & 10 & 3.596 & 1.962 .469 \\
\hline 6 & KEPULAUAN SERIBU & 2 & 39 & 17.452 \\
\hline & JUMLAH & 44 & 12.924 & 7.101.354 \\
\hline
\end{tabular}

Dari angka DPSHP tersebut, yakni 7. 101. 354 jumlah pemilih ada sedikit pengurangan dari jumlah DPS awalnya yang di keluarkan KPU Provinsi pada 2 Nopember 2016 sebanyak 7. 132. 856 pemilih

\section{Hasil Penetapan DPT}

Setelah melalui rangkaian yang cukup panjang, akhirnya sesuai jadwal yang ditentukan, 8 Desember 2016 KPU Provinsi menyelenggarakan Rapat Pleno Terbuka untuk menetapkan DPT setelah mengalami banyak masukan perbaikan. Berikut ini jumlah pemilih Pemilukada DKI Jakarta Tahun 2017 pada DPT yang telah disahkan KPU Provinsi DKI dalam tabel 9, yakni: 
Tabel 9

Jumlah Pemilih Berdasarkan DPS Hasil Perbaikan (DPSHP)

Provinsi DKI Jakarta

\begin{tabular}{|l|c|c|}
\hline \multirow{2}{*}{ Kota/ Kabupaten } & \multicolumn{2}{|c|}{ Data Pemilih Tetap 2017 } \\
\cline { 2 - 3 } & TPS & DPT \\
\hline Jakarta Barat & 2.934 & 1.652 .051 \\
\hline Jakarta Pusat & 1.237 & 747.152 \\
\hline Jakarta Selatan & 2.973 & 1.593 .700 \\
\hline Jakarta Timur & 3.690 & 2.006 .397 \\
\hline Jakarta Utara & 2.150 & 1.091 .874 \\
\hline Kepulauan Seribu & 39 & 17.415 \\
\hline Total & $\mathbf{1 3 . 0 2 3}$ & $\mathbf{7 . 1 0 8 . 5 8 9}$ \\
\hline
\end{tabular}

Jika dicermati, angka DPS yang awalnya berjumlah 7. 132. 856, kemudian turun ketika menjadi DPSHP menjadi 7. 101. 354 pemilih, mengalami kenaikan sedikit pada DPT menjadi angka 7. 108. 589 pemilih.
Namun jika diperbandingkan angka awal DPS menjadi DPT terdapat selisih atau berkurang menjadi 24. 267 pemilih. Sebagaimana pada tabel 10 berikut:

Tabel 10

Selisih Jumlah Pemilih Berdasarkan DPS dan DPT Pilgub Tahun 2017 Provinsi DKI Jakarta Putaran Pertama

\begin{tabular}{|l|c|c|c|c|c|c|}
\hline \multirow{1}{*}{ KOTA/ } & \multicolumn{2}{c|}{ DPS } & \multicolumn{2}{c|}{ DPT } & \multicolumn{2}{c|}{$\begin{array}{c}\text { SELSIH DPT- } \\
\text { DPS }\end{array}$} \\
\cline { 2 - 7 } & TPS & DPS & TPS & DPT & TPS & DPS \\
\hline $\begin{array}{l}\text { JAKARTA } \\
\text { BARAT }\end{array}$ & 2.934 & $\begin{array}{c}1.669 . \\
351\end{array}$ & 2.934 & $\begin{array}{c}1.652 . \\
051\end{array}$ & - & 17.300 \\
\hline $\begin{array}{l}\text { JAKARTA } \\
\text { PUSAT }\end{array}$ & 1.237 & 757.898 & 1.237 & 747.152 & - & 10.746 \\
\hline $\begin{array}{l}\text { JAKARTA } \\
\text { SELATAN }\end{array}$ & 2.973 & $\begin{array}{c}1.599 . \\
920\end{array}$ & 2.973 & $\begin{array}{c}1.593 . \\
700\end{array}$ & 60 & 6.220 \\
\hline $\begin{array}{l}\text { JAKARTA } \\
\text { TIMUR }\end{array}$ & 3.690 & $\begin{array}{c}1.989 . \\
106\end{array}$ & 3.690 & $\begin{array}{c}2.006 . \\
397\end{array}$ & 9 & 17.291 \\
\hline $\begin{array}{l}\text { JAKARTA } \\
\text { UTARA }\end{array}$ & 2.150 & $\begin{array}{c}1.099 . \\
169\end{array}$ & 2.150 & $\begin{array}{c}1.091 . \\
874\end{array}$ & 8 & 7.295 \\
\hline $\begin{array}{l}\text { KEPULAUAN } \\
\text { SERIBU }\end{array}$ & 40 & 17.412 & 39 & 17.415 & 1 & 2 \\
\hline
\end{tabular}




\begin{tabular}{|l|c|c|c|c|c|c|}
\hline TOTAL & 12.067 & $\begin{array}{c}7.132 . \\
856\end{array}$ & 13.023 & $\begin{array}{c}7.108 . \\
589\end{array}$ & 44 & 24.267 \\
\hline
\end{tabular}

\section{Penduduk Pengguna KTP Elektronik} dan Surat Keterangan (SUKET) Disdukcapil Provinsi DKI Jakarta Menjelang hari pencoblosan tanggal 15 Februari sejumlah penduduk di DKI Jakarta ternyata masih dijumpai belum semuanya merekam E-KTP atau terdata dalam database kependudukan. Dari sebanyak 10. 271. 026 jiwa penduduk DKI yang wajib KTP hanya sebesar 7. 389. 470 jiwa. Sedangkan yang telah melakukan perekaman E-KTP sebesar 7. 323. 714 atau $99,1 \%$ dan yang belum sebanyak 65. 756 atau $0,9 \%$. Lihat tabel 11 berikut:

Tabel 11

Jumlah Warga DKI Jakarta Yang Merekam E-KTP Per 28 Januari 2017 (Menjelang Pencoblosan 15 Februari 2017)

\begin{tabular}{|l|l|c|}
\hline Keterangan & Jumlah & \% \\
\hline Jumlah Penduduk Dki Jakarta & 10.271 .026 & \\
\hline Jumlah Penduduk Wajib Ktp & 7.389 .470 & \\
\hline $\begin{array}{l}\text { Jumlah Penduduk Yang Sudah Merekam Ktp } \\
\text { Elektronik }\end{array}$ & 7.323 .714 & 99,1 \\
\hline $\begin{array}{l}\text { Jumlah Penduduk Yang Belum Merekam } \\
\text { Ktp Elektronik }\end{array}$ & 65.756 & 0,9 \\
\hline
\end{tabular}

Sumber Data dari Dinas Kependudukan dan Pencatatan Sipil Provinsi DKI Jakarta, 29 Januari 2017

Adanya sejumlah warga yang belum terekam di atas bakal menyulitkan bagi yang bersangkutan untuk mendapatkan hak pilih terkecuali segera melakukan perekaman sebelum mendekati 3 atau 2 hari menjelang pencoblosan dengan membawa bukti perekaman E-KTP disertai kewajiban didaftar pada pukul 12. 00 atau 1 jam sebelum TPS ditutup jika kertas surat suara masih tersedia.

Pada perkembangannya ternyata terdapat 2 SUKET sebagaimana edaran pemerintah yang resmi dipergunakan salah satu dari keduanya, yakni bentuk SUKET yang sesuai ketentuan berikut: 
1. Surat Kemendagri No. 471. 13/10231/DUKCAPIL, tanggal 29 September 2016

2. Sesuai Surat Kemendagri No. 471. 13/11691/DUKCAPIL, tanggal 3 November 2016

\section{Kisruh Pemilih Pada Pemungutan Suara Pilkada DKI Jakarta Tahun 2017 Putaran Pertama}

Pada putaran pertama Pilkada DKI Jakarta yang berjalan aman tanpa gangguan yang berarti sebagaimana yang diprediksi "rusuh". Namun masih terdapat sedikit kericuhan di berbagai tempat di beberapa TPS di beberapa wilayah. Seperti adanya TPS yang dilakukan PSU (Pemungutan Suara Ulang) pada Minggu, 19 Februari (4 hari sesudah pencoblosan, 15 Februari) sebagaimana pada TPS 01 Kelurahan Utan Panjang di Kemayoran Jakarta Pusat dan TPS 29 Kalibata, di Pancoran Jakarta Selatan dengan cara kertas suara yang digunakan di cap stempel Pemilihan Ulang di setiap lembar surat suara dan Formulir yang digunakan oleh KPU.

Berdasarkan hasil pemantauan penggunaan hak suara pada daftar pemilih tambahan pada Pilgub DKI 2017 putaran pertama yang lalu ditemukan penggunaan bukti identitas kependudukan yang resmi dan tidak resmi untuk pemilihan atau mencoblos pada 15 Februari 2017. Misalnya terdapat sejumlah warga yang menggunakan Surat Keterangan (Suket) yang bukan untuk pemilihan digunakan untuk mendaftar sebagai pemilih dan luput dari perhatian petugas KPPS, PPS, dan akhirnya terbuka pada rekapitulasi penghitungan suara di tingkat kecamatan dan kota di Jakarta Timur, yakni kejadian yang telah ada pada TPS 22 Kelapa Dua Wetan Kecamatan Ciracas.

\section{A. Data Pemilih Pilgub DKI 2017 Putaran} Kedua

1. Data Penduduk DKI Jakarta Menjelang Pemutakhiran Data Pemilih Putaran Kedua (Hasil DP4 Tambahan Maret 2017)

Memasuki tahapan putaran kedua Pilgub DKI Jakarta 2017, KPU RI mengirimkan data tambahan potensi pemilih pemula dan pemilih alih status yang berasal Kementerian Dalam Negeri kepada KPU Provinsi DKI Jakarta pada 8 Maret 2017. Data tambahan tersebut berasal dari Dirjen Dukcapil Kementerian Dalam Negeri melalui surat No. 470/2769/Dukcapil-Ses tertanggal 7 Maret 2017 perihal Penyerahan Data DP4 Tambahan Pemilih Pemula.

Berdasarkan pencermatan KPU RI terdapat tambahan data untuk potensi pemilih 
sebanyak 21. 020 pemilih dengan rincian 20 . 722 adalah jumlah Pemilih Pemula dan 298 adalah pemilih alih status dari TNI/Polri menjadi warga sipil. Data tersebut menjadi bahan masukan DPS bagi KPU Provinsi dan
KPU Kab/Kota di DKI Jakarta untuk diverifikasi atau dimutakhirkan.

Tabel 12 berikut ini merupakan rekapitulasi daftar pemilih alih status dari KPU RI.

Tabel 12

Data DP4 Tambahan Putaran Kedua Khusus Alih Status

\begin{tabular}{|c|c|c|c|c|}
\hline \multirow{2}{*}{ No. } & \multirow{2}{*}{ Nama Kabupaten/Kota } & \multicolumn{3}{|c|}{ Jumlah Pemilih Alih Status } \\
\cline { 3 - 5 } & L & $\mathbf{P}$ & L+P \\
\hline $\mathbf{1}$ & Jakarta Pusat & 16 & 1 & 17 \\
\hline $\mathbf{2}$ & Jakarta Utara & 32 & 4 & 36 \\
\hline $\mathbf{3}$ & Jakarta Barat & 27 & 2 & 29 \\
\hline $\mathbf{4}$ & Jakarta Selatan & 68 & 5 & 73 \\
\hline $\mathbf{5}$ & Jakarta Timur & 130 & 13 & 143 \\
\hline $\mathbf{6}$ & Kepulauan Seribu & - & - & - \\
\hline & TOTAL & $\mathbf{2 7 3}$ & $\mathbf{2 5}$ & $\mathbf{2 9 8}$ \\
\hline
\end{tabular}

\section{Pemutakhiran Data Pemilih sejak DPS sampai ditetapkannya DPT oleh KPU DKI.}

Berbeda dengan pemutakhiran data pemilih pada Pilgub DKI Jakarta Tahun 2017 Putaran Pertama yang dilakukan secara faktual atau mekanisme Coklit (Pencocokan dan Penelitian) di lapangan, maka pada putaran kedua pemutakhiran data pemilih dilakukan secara administratif sampai tingkat Kelurahan melalui PPS. Cara Pemutakhiran Daftar Pemilih Putaran Kedua dilakukan dengan memperbaiki DPT putaran I dan melakukan input DPTb putaran I setelah dilakukan verifikasi administrasi oleh KPU
Kab/Kota dibantu PPK dan PPS dalam melakukan pemutakhiran berbasis TPS (maksimal 800 pemilih).

Pada putaran kedua, calon pemilih dihimbau aktif mendaftar diri jika sebelumnya tidak terdaftar pada DPT Putaran pertama yang dilayani sejak Pagi (10. 00-17. 00 WIB) dan Malam hari (20. 00-23. 00 WIB) dalam waktu yang relatif singkat (7 hari). Puncaknya, melalui rapat Pleno Terbuka Rekapitulasi DPS Tingkat Provinsi Pada Pilgub DKI Jakarta Tahun 2017 Putaran Kedua, Selasa 21 Maret 2017 bertempat di Grand Ballroom, Hotel Oasis Amir, Senen Raya Jakarta Pusat, pukul 19. 30 WIB 
didapati sebanyak 7. 264. 749 total pemilih dengan rincian pemilih laki-laki sebanyak 3 . 634. 585 dan perempuan sebanyak 3. 630.
164 pada rekapitulasi DPS putaran kedua sebagaimana berikut:

Tabel 13

Data DPS Pilgub DKI Jakarta 2017 Putaran Kedua

\begin{tabular}{|c|c|c|c|c|}
\hline \multirow{2}{*}{ No } & \multirow{2}{*}{$\begin{array}{c}\text { Nama } \\
\text { Kabupaten/Kota }\end{array}$} & $\mathbf{L}$ & $\mathbf{P}$ & Jumlah Pemilih Dalam DPS \\
\cline { 3 - 5 }$\cdot$ & & 382.759 & 382.263 & 765.122 \\
\hline $\mathbf{1}$ & Jakarta Pusat & 563.284 & 561.148 & 1.124 .432 \\
\hline $\mathbf{2}$ & Jakarta Utara & 850.402 & 836.231 & 1.686 .633 \\
\hline $\mathbf{3}$ & Jakarta Barat & 812.197 & 815.386 & 1.627 .583 \\
\hline $\mathbf{4}$ & Jakarta Selatan & 1.016 .971 & 1.026 .250 & 2.043 .221 \\
\hline $\mathbf{5}$ & Jakarta Timur & 8.972 & 8.786 & 17.758 \\
\hline $\mathbf{6}$ & Kepulauan Seribu & $\mathbf{3 . 6 3 4 . 5 8 5}$ & $\mathbf{3 . 6 3 0 . 1 6 4}$ & $\mathbf{7 . 2 6 4 . 7 4 9}$ \\
\hline
\end{tabular}

Hasil DPS yang berhasil direkapitulasi pada tabel 13 di atas, berikutnya diserahkan kembali ke KPU Kab/Kota masing-masing wilayah yang berupa salinan DPS untuk disampaikan kepada PPS melalui PPK sebanyak 3 rangkap guna ditempel pada papan pengumuman di kantor kelurahan; di sekretariat/balai Rukun Tetangga (RT)/Rukun Warga (RW) atau tempat strategis lainnya; dan untuk Arsip PPS bersangkutan. Diumumkannya DPS oleh PPS untuk mendapatkan masukan dari masyarakat sekitar dan selanjutnya disusun DPS hasil perbaikan (DPSHP) secara berjenjang mulai dari PPS, PPK, Hingga KPU Kab/Kota maupun Provinsi.

DPT Putaran Kedua yang ditetapkan KPU DKI Jakarta melalui Rapat Pleno Rekapitulasi DPT Tingkat Provinsi di Hotel Bidakara, Kamis, 6 April hingga Jumat dini hari, 7 April 2017 didapati sejumlah 7. 218. 254 pemilih dan terdapat tambahan 26 pemilih dari Jakarta Barat sehingga menjadi 7. 218. 280 yang berarti hanya ada sedikit penurunan dari DPS yang awalnya 7. 264. 749 setelah diperbaiki, sebagaimana pada tabel 14 berikut: 
Tabel 14

DPT PILKADA DKI PUTARAN KEDUA TAHUN 2017

\begin{tabular}{|c|c|c|c|c|c|}
\hline No & КАВ/КОТА & JML TPS & $\begin{array}{l}\text { LAKI- } \\
\text { LAKI }\end{array}$ & $\begin{array}{c}\text { PEREMPU } \\
\text { AN }\end{array}$ & $\begin{array}{r}\text { TOTAL } \\
\text { DPT } \\
\end{array}$ \\
\hline 1 & Jakarta Barat & 2.935 & 848.113 & 833.359 & 1.681 .496 \\
\hline 2 & Jakarta Pusat & 1.238 & 378.648 & 378.867 & 757.515 \\
\hline 3 & Jakarta Selatan & 2.974 & 801.668 & 805.253 & 1.606 .921 \\
\hline 4 & Jakarta Timur & 3.698 & 1.007 .452 & 1.017 .705 & 2.025 .157 \\
\hline 5 & Jakarta Utara & 2.150 & 565.244 & 564.250 & 1.129 .494 \\
\hline 6 & Kepulauan Seribu & 39 & 8.943 & 8.752 & 17.695 \\
\hline & TOTAL & 13.034 & 3. 610. & 3. ${ }_{186}^{608 .}$ & 7. ${ }_{280}^{218 .}$ \\
\hline
\end{tabular}

DPT Pilkada DKI Jakarta 2017 putaran kedua sebanyak 7. 218. 280 dan tersebar di 13. 034 tempat pemungutan suara (TPS) jika dibandingkan dengan DPT Pilkada DKI Putaran Pertama yang banyaknya 7. 108. 589 pemilih yang tersebar di 13. 023 TPS, berarti ada tambahan 109. 691 pemilih dan 11 TPS baru.

Selama kegiatan Pemutakhiran data secara administratif oleh KPU Kab/Kota hingga PPK dan PPS, terdapat banyak masalah yang patut dipertanyakan oleh sejumlah kalangan mengenai keakuratan data pemilih, baik pada DPS, DPSHP, dan bahkan DPT. Bahkan dari pihak Pasangan Calon yang disampaikan oleh Tim Kampanye Pasangan Calon Gubernur Nomor Urut 3 (Tiga) Anies R. Baswedan dan Sandiaga S. Uno melansir temuan terhadap ratusan ribu data invalid dari DPS Pemilihan Bubernur DKI Jakarta Tahun 2017 Putaran Kedua.

Pada akhirnya, tepat hari Senin malam, 10 April 2017 terjadi Rapat Sinkronisasi Data Pemilih antara KPU Provinsi, Bawaslu DKI, Disdukcapil DKI, dan Tim Pasangan Calon Nomor 2 dan 3 membahas adanya penyisiran data kependudukan berdasarkan aduan atas temuan tersebut yang sudah dilakukan oleh Disdukcapil DKI sebagaimana tabel 15 berikut: 
Tabel 15

Rekapitulasi Hasil Penyisiran Data Kependudukan Dalam Sinkronisasi Data

Pemilih Pilgub 2017 Putaran Kedua

\begin{tabular}{|c|l|c|c|c|c|}
\hline No & \multicolumn{1}{|c|}{ Kab/Kota } & Meninggal & $\begin{array}{c}\text { Pindah } \\
\text { Keluar } \\
\text { DKI }\end{array}$ & $\begin{array}{c}\text { Tidak ada } \\
\text { dalam } \\
\text { Database } \\
\text { Adminduk }\end{array}$ & Jumlah \\
\hline 1 & KepulauanSeribu & 0 & 0 & 5 & 5 \\
\hline 2 & Jakarta Pusat & 2 & 21 & 577 & 600 \\
\hline 3 & Jakarta Utara & 0 & 1 & 520 & 521 \\
\hline 4 & Jakarta Barat & 0 & 0 & 4.805 & 4.805 \\
\hline 5 & Jakarta Selatan & 7 & 9 & 609 & 625 \\
\hline 6 & Jakarta Timur & 0 & 1 & 9.397 & 9.398 \\
\hline & Jumlah & 9 & 32 & 15.913 & 15.954 \\
\hline
\end{tabular}

Dari hasil rapat sinkronisasi data pemilih pada DPT Putaran Kedua Pemilihan Gubernur dan Wakil Gubernur DKI Jakarta Tahun 2017 tersebut di atas, kemudian dibuat kesepakatan dalam Berita Acara yang berisikan hal-hal sebagai berikut, di antaranya:

1. Pemilih yang tidak memenuhi syarat karena tidak ada dalam database kependudukan DKI Jakarta, meninggal dunia dan pindah domisili keluar DKI Jakarta dengan rincian di atas (total sebanyak 15. 954 pemilih) dikategorikan sebagai pemilih yang tidak memenuhi syarat, dan KPU Provinsi DKI Jakarta akan melakukan pengarsiran dan memberi keterangan pada pemilih sesuai dengan kategori tersebut di atas dalam Daftar Pemilih Tetap (DPT) Putaran Kedua yang dilaksanakan oleh KPU Kabupaten/Kota se-DKI Jakarta.

Apabila ditemukan data ganda dalam DPT Putaran Kedua, maka petugas KPPS mengembalikan formulir C6 kepada PPSdan direkap dalam formulir D2 KWKII

\section{Perkembangan Warga Penduduk}

Pemilik E-KTP dan Surat Keterangan (SUKET) dari Disdukcapil Menjelang Putaran Kedua 19 April 2017

Pada Pilgub DKI Jakarta putaran pertama jumlah Surat keterangan yang diterbitkan oleh Disdukcapil sampai H-1 pencobosan sebanyak 84. 000. Pasca 
pencoblosan, menjelang tahapan pemutakhiraan data pemilih untuk putaran kedua, Disdukcapil DKI melansir hasil Rekapitulasi Surat Keterangan Pengganti KTP-el dan Surat Keterangan (Suket) Terdaftar dalam Database Dinas Kependudukan Kota/Kab Provinsi DKI
Jakarta. Suket yang direkap adalah yang tidak terdaftar di Daftar Pemilih Tetap (DPT) putaran pertama PILKADA tahun 2017 pertanggal 16 Februari sampai dengan 12 Maret 2017, sebagaimana hasil rekapitulasi pada tabel 16 berikut:

Tabel 16

Rekapitulasi Hasil Database Kependudukan Pengguna SUKET Menjelang Pemutakhiran Data Pemilih Pilgub DKI 2017 Putaran Kedua

\begin{tabular}{|c|l|c|c|c|}
\hline \multirow{2}{*}{ No. } & \multirow{2}{*}{ KAB/KOTA } & \multicolumn{2}{|c|}{ Pertanggal 16 Februari s. d. 12 Maret 2017 } & \multirow{2}{*}{ Jenis Surat Keterangan } \\
\cline { 3 - 4 } & & Pengganti Ktp-EI & $\begin{array}{c}\text { Terdaftar Dalam Data } \\
\text { Base }\end{array}$ & \\
\hline 1 & JUMLAH \\
\hline 2 & Jepulauan Seribu & 12 & 0 & 12 \\
\hline 3 & Jakarta Pusat & 706 & 570 & 1.276 \\
\hline 4 & Jakarta Utara & 2.970 & 2.252 & 5.222 \\
\hline 5 & Jakarta Selatan & 3.137 & 1.983 & 5.120 \\
\hline 6 & Jakarta Timur & 2.760 & 1.401 & 4.161 \\
\hline \multicolumn{2}{|c|}{ TOTAL } & 4.239 & 2.781 & 7.020 \\
\hline
\end{tabular}

Sementara itu, Tim Kampanye Pasangan calon Nomor 3 Anies-Sandi melansir temuannya terhadap keberadaan Suket tersebut di atas. Analisis Tim Bidang Data Anies-Sandi dengan cara melakukan analisa terhadap administrasi kependudukannya yaitu; Nomor Induk Kependudukan (NIK) dan Nomor Kartu Keluarga (KK) pada Daftar Penerbitan SUKET yang disampaikan kepada KPUD DKI untuk dimasukkan dalam Daftar Pemilih Tetap (DPT) putaran kedua, sebagaimana pada tabel 17 berikut: 
Tabel 17

Rekapitulasi Temuan Data Pengguna SUKET Kependudukan Bermasalah Menjelang Pemungutan Suara Pilgub DKI 2017 Putaran Kedua

\begin{tabular}{|c|l|c|}
\hline KATEGORI & \multicolumn{1}{|c|}{ KETERANGAN } & $\begin{array}{c}\text { JUMLAH } \\
\text { TEMUAN }\end{array}$ \\
\hline Iinvalid "I" & $\begin{array}{l}\text { NIK format tanggal tidak terbaca / tidak } \\
\text { sesuai jenis }\end{array}$ & 333 \\
\hline Invalid "J" & $\begin{array}{l}\text { NIK kode Provinsi di luar dalam wilayah } \\
\text { kependudukan }\end{array}$ & 31 \\
\hline Invalid "K" & $\begin{array}{l}\text { NIK kode Kab/Kota di luar dalam wilayah } \\
\text { kependudukan }\end{array}$ & 25 \\
\hline Invalid "L" & $\begin{array}{l}\text { NIK kode Kecamatan di luar dalam wilayah } \\
\text { kependudukan }\end{array}$ & 41 \\
\hline & \multicolumn{1}{|c|}{ JUMLAH } & $\mathbf{4 3 0}$ \\
\hline
\end{tabular}


Temuan Tim Kampanye Pasangan calon Nomor 3 Anies-Sandi ataskeberadaan Suket tersebut di atas yang masing bermasalah dengan administrasi kependudukannya sebanyak 22. 811 warga. Mengingat penerbitan Suket ini rawan politisasi menjelang pemungutan suara putaran kedua, disertai pengalaman putaran pertama yang masuk dalam "gerombolan" DPTb dengan temuan adanya Suket "palsu" yang digunakan untuk mencoblos, maka Tim Kampanye Anies-Sandi dari Partai Gerindra dan PKS mengusulkan pada KPU DKI, Bawaslu DKI, agar Disdukcapil menerbitkan Suket dibatasi. Mengingat akan menjadi sumber kerawanan politik dengan adanya mobilisasi besar-besaran warga pendatang untuk mengurus Suket yang berpotensi konflik dan kecurangan.

\section{PENUTUP}

Pemutakhiran "penduduk politik" yakni warga yang dipersyaratkan menggunakan hak politik untuk didaftar sebagai pemilih dalam data pemilih pada Pilgub DKI Jakarta 2017 perjalanannya sangat rumit dan kompleks mengingat dinamika kependudukannya yang tinggi menjelang pemungutan suara. Selain tingkat kesibukan pekerjaan dan lokasi domisili yang sulit ditemui saat Coklit data, juga khususnya warga pendatang urban yang selalu bertambah sehingga pemutakhiran data yang terbatas untuk kepentingan logistik pemungutan suara belum mampu menjangkau laju kependudukan. Kebijakan diikeluarkannya SUKET sebagai pengganti sementara identitas kependudukan (selama blangko EKTP belum tersedia) kian menyeret Disdukcapil selaku instansi pemerintah DKI untuk ikut serta menyediakan perangkat keabsahan data administrasi kependudukan sebagai syarat warga memilih. Disdukcapil seolah terlibat sebagai "penyelenggara bayangan" pada perhelatan data pemilih Pilgub 2017.

Pada Pemungutan Suara Pilgub DKI Jakarta Putaran Pertama, 15 Februari 2017 pemilih yang mendaftar menggunakan lembar DPTb sebanyak 237. 003 yang digunakan pada saat pencoblosan dari jumlah pemilih yang menggunakan haknya sebanyak 5. 564. 313. Jumlah DPTb ternyata cukup signifikan bagi perolehan suara jika dilihat dari hasil hitung antara selisih antara pasangan calon Nomor 2 dan 3, yang masing-masing memperoleh 2. 364 . 577 suara $(42,99$ persen $)$ pada Basuki-Djarot, dan Pasangan Calon Nomor Urut 3 meraih 2. 197. 333 (39. 95 persen) pada Anies-Sandi. Selisih antara keduanya hanya terpaut 167. 244 suara. Artinya suara dari pemilih DPTb lebih besar dari selisih keduanya. 
Dari analisa lembaga survey, sebaran pemilih pengguna DPTb pada putaran pertama tenyata banyak terdapat di 542 TPS yang jumlahnya lebih banyak memenangkan pasangan Basuki-Djarot lebih dari 90 persen. Sisanya memilih pasangan Anies-Sandi dan AHY-Silvy. Lokasi terbanyak pengguna DPTb ada di Jak arta Utara dan Jakarta Barat sebagai basis wilayah yang memenangkan pasangan Basuki-Djarot pada putaran pertama.

\section{Memasuki Pilgub DKI putaran} kedua, pemilih dalam DPTb kembali menjadi sorotan tajam dari pemerhati pemilu dan masyarakat luas, sehingga perlunya pemutakhiran yang benar-benar cermat. Mengingat dalam pemutakhiran DPS putaran kedua adalah DPT Putaran Pertama ditambah pemilih DPTb hasil putaran pertama. Perjalanannya, DPT putaran kedua yang sudah direkapitulasi tingkat Provinsi pada6 April 2017 ternyata masih menyisakan problem, yakni temuan sejumlah data penduduk yang invalid. Dari sejumlah 7. 218. 280 total pemilih dalam DPT terdapat sebanyak 15. 954 dikategorikan sebagai pemilih yang tidak memenuhi syarat, dan KPUProvinsi DKI Jakarta akan melakukan pengarsiran dan memberi keterangan pada pemilih sesuai dengan kategori tersebut di atas dalam Daftar Pemilih Tetap (DPT) Putaran Kedua yang dilaksanakan oleh KPU Kabupaten/Kota se-DKI Jakarta.

Dengan demikian, perjalanan data pemilih pada Pilgub DKI Jakarta 2017 belum mampu menjawab akurasi dan kevalidan data pemilih sepenuhnya yang diidentifikasi sebagai warga pengguna hak pilih di DKI Jakarta. Masalah tersebut selain karena tingkat dinamika kependudukan yang tinggi menjelang Pilgub, juga terkait dengan tingkat keabsahan data kependudukan yang berpangkal dari administrasi kependudukan di intansi pemerintah Disdukcapil dan Kementerian Dalam Negeri. Hal ini dibuktikan dengan masalah perekaman identitas kependudukan dan fenomena "SUKET" yang bervariasi sehingga turut berkontribusi pada kekisruhan selama pemutakhiran dan penetapan data pemilih hingga pemungutan suara. Kenyataan demikian yang mengakibat KPU DKI harus "pontang-panting" memverifikasi dan melakukan validasi serta mengklarifikasi berbagai kritik, masukan dan aspirasi yang berkembang di masyarakat akan adanya pemilih "siluman" dan dicurigai untuk kepentingan politik pasangan tertentu.

\section{DAFTAR PUSTAKA}

Ida Bagoes Mantra. 2011. Demografi Umum. Yogyakarta: Pustaka Pelajar 
Sudjarwo S. 2004. Buku Pintar

Kependudukan. Jakarta: PT. Gramedia Widiasarana Indonesia

Triyuni Soemartono dan Sri Hendrastuti. 2011. Administrasi Kependudukan Berbasis Registrasi. Yayasan Bina Profesi Mandiri

Undang-Undang RI Nomor 23 Tahun 2014 tentang Pemerintah Daerah

Undang-Undang RI Nomor 2 Tahun 2015 tentang Penetapan Peraturan Pemerintah Pengganti Undang Undang (Perppu) Nomor 2 Tahun 2014 tentang Perubahan Atas UU Nomor 23/2014 Menjadi UndangUndang.

Undang-Undang RI Nomor 9 Tahun 2015 tentang Perubahan Kedua Atas UU Nomor 23 Tahun 2014 tentang Pemerintah Daerah (disahkan dan diundangkan pada 18 Maret 2015 dalam Lembaran Negara Republik Indonesia tahun 2015 Nomor 58).

Undang-Undang RI Nomor 29 tahun 2007 tentang Pemerintahan Provinsi Daerah Khusus Ibukota Jakarta Sebagai Ibukota Negara Kesatuan Republik Indonesia

Undang-Undang RI Nomor 23 tahun 2006 tentang Administrasi Kependudukan

Undang-Undang RI Nomor 24 Tahun 2013 tentang Administrasi Kependudukan

UU Nomor 1 Tahun 2015 Tentang Penetapan Peraturan Pemerintah Pengganti Undang-Undang Nomor 1 Tahun 2014 Tentang
Pemilihan Gubernur, Bupati, dan Walikota Menjadi UndangUndang

UU Nomor 8 Tahun 2015 tentang Perubahan atas UU Nomor 1 tahun 2015 tentang Penetapan Perppu Nomor 1 Tahun 2014 tentang Pemilihan Gubernur, Bupati, dan Walikota menjadi Undang-Undang

UU Nomor 10 Tahun 2016 tentang Perubahan Kedua atas UU Nomor 1 tahun 2015 tentang Penetapan Perppu Nomor 1 Tahun 2014 tentang Pemilihan Gubernur, Bupati, dan Walikota menjadi Undang-Undang

Peraturan Pemerintah Nomor 37 tahun 2007 tentang Pelaksanaan Undang-Undang Nomor 23 tahun 2006 tentang Administrasi Kependudukan yang meliputi pelaksanaan Sistem Informasi Administrasi Kependudukan (SIAK).

Peraturan Presiden RI Nomor 26 Tahun 2009 tentang Penerapan KTP Berbasis NIK Secara Nasional

Peraturan Presiden RI Nomor 35 Tahun 2010 tentang Perubahan atas Peraturan Presiden Nomor 26 Tahun 2009 tentang Penerapan KTP Berbasis NIK Secara Nasional

Peraturan Presiden RI Nomor 112 Tahun 2013 tentang Perubahan Keempat atas Peraturan Presiden Nomor 26 Tahun 2009 tentang Penerapan KTP Berbasis NIK Secara Nasional 
Keputusan Presiden Nomor 88 tahun 2004 tentang Pengelolaan Administrasi Kependudukan

Peraturan KPU Nomor 4 tahun 2015 tentang Pemutakhiran Data dan Daftar Pemilih Dalam Pemilihan Gubernur dan Wakil Gubernur, Bupati dan Wakil Bupati dan/atau Walikota dan Wakil Walikota

Peraturan KPU Nomor 8 tahun 2016 tentang Perubahan Atas Peraturan KPU Nomor 4 tahun 2015 Pemutakhiran Data dan Daftar Pemilih Dalam Pemilihan Gubernur dan Wakil Gubernur, Bupati dan Wakil Bupati dan/atau Walikota dan Wakil Walikota

Keputusan KPU Provinsi DKI Jakarta No. 24/kpts/KPU-Prov010/Tahun 2016 Tentang Perubahan Atas Keputusan KPU Provinsi DKI Jakarta No. 05/ kpts/KPU-Prov-010/Tahun 2016 Tentang Tahapan, Program, dan Jadwal Penyelenggaraan Pemilihan Gubernur dan Wakil Gubernur Provinsi DKI Jakarta Tahun 2017

Surat Keputusan bernomor 48/Kpts/KPU-Prov-010/2017 tentang Pasangan Calon Peserta
Pemilihan Gubernur dan Wakil Gubernur Provinsi DKI Jakarta Tahun 2017 Putaran Kedua

Surat Kemendagri No. 471. 13/10231/DUKCAPIL, tanggal 29 September 2016

Surat Kemendagri No. 471. 13/11691/DUKCAPIL, tanggal 3 November 2016

Rakyat Merdeka Online (RMOL), Jakarta. Jumat, 17 Februari 2017, http://m. rmoljakarta. com/news. php?id=42689

Tempo. Co, Jakarta. Pilkada DKI, Tim Anies - Sandi Temukan 153 Ribu Data Invalid (1 April 2017). Dapat dilihat dalam berita online melalui situs: https://m. tempo. co/read/news/2017/04/01/348861754 /pilkada-dki-tim-anies-sanditemukan-153-ribu-data-invalid

Teropong Senayan, Jakarta. Tim AniesSandi Serahkan 13 Temuan Keganjilan DPS ke KPU DKI (Sabtu, 1 April 2017). Dapat dilihat versi berita versi online tersebut dalam situs: http://www. teropongsenayan. com/60405-timanies-sandi-serahkan-13-temuankeganjilan-dps-ke-kpu-dki 